Stephen E. Kesler · Charles W. Carrigan

\title{
Discussion on "Mississippi Valley-type lead-zinc deposits through geological time: implications from recent age-dating research" by D.L. Leach, D. Bradley, M.T. Lewchuk, D.T.A. Symons, G. de Marsily, and J. Brannon (2001) Mineralium Deposita 36:711-740
}

Received: 14 February 2002 / Accepted: 14 February 2002 / Published online: 7 June 2002

(C) Springer-Verlag 2002

Keywords Age-dating research $\cdot$ Lead-zinc deposits Mississippi Valley

\section{Introduction}

In their comprehensive and interesting summary of recent research on ages of MVT mineralization, Leach et al. state that "Evaluating the possible fluid-flow mechanisms for the East Tennessee ores with respect to the $\mathrm{Rb}-\mathrm{Sr}$ dates is difficult because the Acadian orogeny did not greatly affect the southern Appalachians and Appalachian Valley and Ridge province." This statement ignores recent isotopic age measurements in the Appalachian hinterland and thereby misses an opportunity for additional insights into the relation between MVT mineralization and contractional tectonics.

The $\mathrm{Rb}-\mathrm{Sr}$ ages of interest here are isochrons obtained on sphalerite from the Coy and Immel mines, which yielded ages of $377 \pm 29$ and $347 \pm 20 \mathrm{Ma}$, respectively (Nakai et al. 1990, 1993). These $\mathrm{Rb}-\mathrm{Sr}$ ages are significantly older than several paleomagnetic, $\mathrm{K}-\mathrm{Ar}$ and $\mathrm{Ar}-\mathrm{Ar}$ measurements indicating that widespread fluid-rock interaction took place in the southern Appalachians between about 320 and $280 \mathrm{Ma}$ (Bachtadse et al. 1987; Elliot and Aronson 1987; Hearn et al. 1987; Symons and Stratakos 2000). These younger ages coincide with the Alleghanian orogeny, which produced widespread stratigraphic and structural features in the southern Appalachians and could have been an important driving force for MVT-mineralizing fluids. In contrast, the $\mathrm{Rb}-\mathrm{Sr}$ ages coincide with the Acadian orogeny, which did not produce obvious stratigraphic or structural features in the southern Appalachians. Until recently, this absence of prominent Acadian features has weakened the case for widespread basinal fluid migration and MVT ore formation during Acadian time.

\section{Editiorial handling: R.J. Goldfarb}

S.E. Kesler $(\square)$

Department of Geological Sciences,

University of Michigan,

Ann Arbor, MI 48109, USA

E-mail: skesler@umich.edu

C.W. Carrigan

Department of Geological Sciences,

University of Michigan,

Ann Arbor, MI 48109, USA

\section{Evidence for an Acadian event in the southern Appalachians}

The southern Appalachian Inner Piedmont (IP) terrane is now considered the Acadian metamorphic core (Hatcher 1998). Recently, multiple workers using a variety of geochronometers have obtained Acadian metamorphic ages in the IP, and also across the orogen in the western and eastern Blue Ridge (WBR and EBR; Fig. 1). Ion probe $\mathrm{U}-\mathrm{Pb}$ analyses of homogeneous, metamorphic zircon rims from the EBR and IP of North Carolina yielded a well-defined age of $\sim 350$ Ma (Bream et al. 2001; Carrigan et al. 2001) that agrees well with a previous $\mathrm{U}-\mathrm{Pb}$ zircon lower intercept of $334 \pm 15 \mathrm{Ma}$ from basement in the EBR (Quinn and Wright 1993). Although the exact timing and mechanism for zircon recrystallization is still a matter of debate, it undoubtedly occurs during high-grade metamorphism (e.g., Fraser et al. 1997; Roberts and Finger 1997; Schaltegger et al. 1999; Moecher and Miller 2000; Rubatto et al. 2001). These Acadian metamorphic zircon rims are found in a variety of rock types and ages, including Grenville basement, Neoproterozoic metasedimentary rocks, and early Paleozoic (Taconic) intrusions. Additionally, electron microprobe total U-Th-Pb ages on monazites from the IP of Georgia yield ages of $330 \pm 15 \mathrm{Ma}$ (Mirante 2001), and conventional $\mathrm{U}-\mathrm{Pb}$ analyses of monazite from the IP of South Carolina also yield Acadian ages of $\sim 360$ and $\sim 320 \mathrm{Ma}$ (Dennis and Wright 1997).

Metamorphic zircon rims in the western EBR are Taconic ( $\sim 40 \mathrm{Ma}$; Moecher and Miller), suggesting that Acadian metamorphism did not reach the high-grade conditions required to recrystallize zircon in the western regions of the southern Appalachian orogen. However, other chronometers record similar Acadian metamorphic ages in the WBR, indicating that Acadian metamorphism did extend across the orogen. Electron microprobe total $\mathrm{U}-\mathrm{Th}-\mathrm{Pb}$ ages on monazite from the Great Smokey Mountains of Tennessee and North Carolina yielded an age of $370 \pm 20 \mathrm{Ma}$ (Kohn 2001). Additionally, Sm-Nd and Rb-Sr mineral isochrons yielded Acadian ages of $375 \pm 27$ and $397 \pm 14 \mathrm{Ma}$ in the Spruce Pine thrust sheet of the WBR (Goldberg and Dallmeyer 1997), and ${ }^{40} \mathrm{Ar} /{ }^{39} \mathrm{Ar}$ methods have yielded ages of $\sim 385-320 \mathrm{Ma}$ on muscovite from the Mt. Mitchell area (Hames et al. 2001). In addition to these isotopic ages, Unrug et al. (2000) have reported fossil assemblages indicating a Silurian or younger age for the Walden Creek Group, a part of the Ocoee Supergroup in the WBR, and have suggested that it was deposited in a pull-apart basin that formed during an Acadian transtensional event.

\section{Significance of the Acadian event to MVT mineralization}

These data clearly provide strong evidence for a widespread Acadian-age tectonothermal event in the southern Appalachian Blue 
Fig. 1 A Generalized tectonic map of the southern Appalachians modified from Hatcher (1989) showing major terranes and locations of Acadian zircon and monazite metamorphic ages (Dennis and Wright 1997; Carrigan et al. 2001; Kohn 2001; Mirante 2001) and MVT deposits (Nakai et al. 1990, 1993); sample locations are approximate. Major terrane boundary faults include 1 Carolina suture, 2 Brevard fault zone, 3 Hayesville-Gossan Lead-Burnsville suture, 4 Great Smokey fault. B Map of the United States showing location of tectonic map (A). C Timeline showing ages of zircon, monazite and sphalerite related to the Acadian orogeny in the southern Appalachians. No errors available for Dennis and Wright (1997) monazite ages. Other published $\mathrm{Sm}-\mathrm{Nd}$, $\mathrm{Rb}-\mathrm{Sr}$, and ${ }^{40} \mathrm{Ar} /{ }^{39} \mathrm{Ar}$ age data are not show in $\mathbf{A}$ or $\mathbf{C}$; see text for discussion

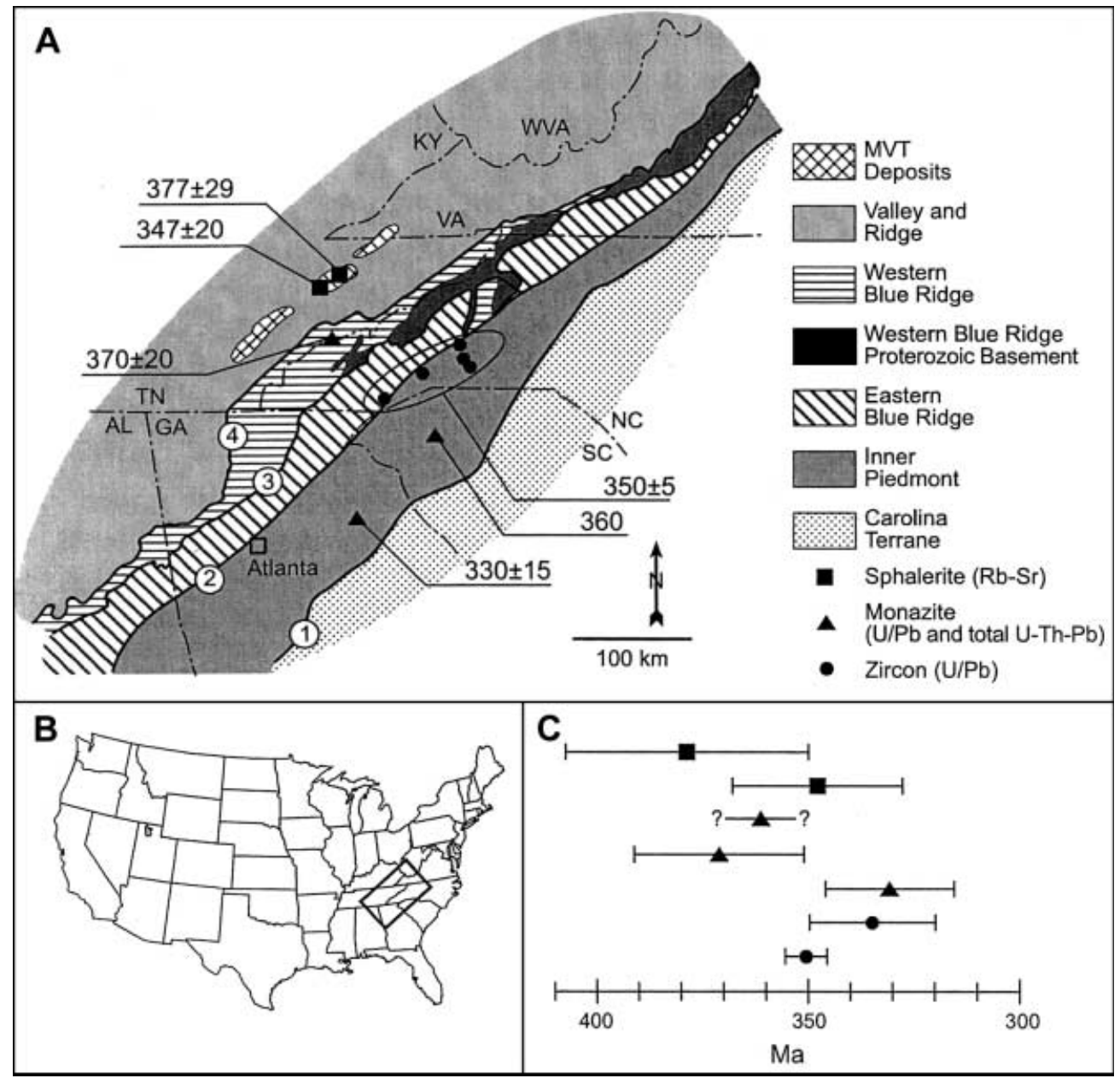

Ridge and Piedmont terranes at about 360-340 Ma. Rocks that reflect this Acadian event comprise the hinterland for the sedimentary sequence that hosts MVT mineralization in the East Tennessee and nearby Copper Ridge and Sweetwater districts (Fig. 1A). With the exception of the $\mathrm{Rb}-\mathrm{Sr}$ mineral isochron in the Spruce Pine thrust sheet, all of these Acadian hinterland ages are similar within analytical error to the $\mathrm{Rb}-\mathrm{Sr}$ isochron ages on MVTsphalerite (Fig. 1C). These observations indicate that MVT deposits in eastern Tennessee formed during the Acadian orogeny. Foreland sequences hosting these MVT deposits underwent a second fluid flow event during the Alleghanian orogeny, which produced the widespread effects noted above, but that did not form the East Tennessee MVT deposits.

These relations confirm that orogenic events can generate important MVT deposits, but leave little or no structural and stratigraphic evidence in the MVT-hosting foreland and be largely obliterated by later orogenic events in the hinterland. This is particularly true if the MVT-forming orogeny is followed by another orogeny, as was the case in the southern Appalachians. This, in turn, provides an important note of caution as we attempt to link MVT-formation to global tectonic events. The Pine Point district provides an example of the problems that we face. Here also, $\mathrm{Rb}-\mathrm{Sr}$ ages for sphalerite are older than the major fluid flow event of Cordilleran age, which has been linked to MVT mineralization by theoretical models of fluid flow and paleomagnetic and fission track measurements (Garven 1985; Symons et al. 1993; Ravenhurst et al. 1994). If insights from the Appalachians can be transferred to this area, the simplest interpretation of these measurements is that the $\mathrm{Rb}-\mathrm{Sr}$ ages on sphalerite record the fluid flow event that formed MVT mineralization, whereas the more indirect age measurements record a later flow event (Symons et al. 1996; Leach et al. 2001).
There is no reason that MVT deposits were formed by the latest or even the most pervasive fluid-flow event in an area, and this underscores the need for continued efforts to measure the isotopic age of actual ore minerals in these deposits.

\section{References}

Bachtadse V, Van der Voo R, Haynes FM, Kesler SE (1987) Late Paleozoic magnetism of mineralized and unmineralized Ordovician carbonates from East Tennessee: evidence for post-ore chemical event. J Geophys Res 92:14165-14176

Bream BR, Hatcher RD, Miller CF, Carrigan CW, Fullagar PD (2001) Provenance and geochemistry of late Proterozoic southern Appalachian crystalline core paragneisses, NC-SCGA-TN. Geol Soc Am Abstr Programs 33(6):A-29

Carrigan CW, Bream BR, Miller CF, Hatcher RD Jr (2001) Ion microprobe analyses of zircon rims from the eastern Blue Ridge and Inner Piedmont, NC-SC-GA: implications for the timing of Paleozoic metamorphism in the southern Appalachians. Geol Soc Am Abstr Programs 33(2):A-7

Dennis AJ, Wright JE (1997) Middle and late Paleozoic monazite $\mathrm{U}-\mathrm{Pb}$ ages, Inner Piedmont, South Carolina. Geol Soc Am Abstr Programs 29(3):12

Elliot WC, Aronson JJ (1987) Alleghenian episode of K-bentonite illitization in the southern Appalachian Basin. Geology 15:735739

Fraser G, Ellis D, Eggins S (1997) Zirconium abundance in granulite-facies minerals, with implications for zircon geochronology in high-grade rocks. Geology 25:607-610 
Garven G (1985) The role of regional fluid flow in the genesis of the Pine Point deposit, Western Canada sedimentary basin. Econ Geol 80:307-324

Goldberg SA, Dallmeyer RD (1997) Chronology of Paleozoic metamorphism and deformation in the Blue Ridge thrust complex, North Carolina and Tennessee. Am J Sci 297:488-526

Hames WE, Steltenpohl MG, Tracy RJ (2001) Applications of laser ${ }^{40} \mathrm{Ar} /{ }^{39} \mathrm{Ar}$ dating to studies of Appalachian metamorphic evolution, examples from New England and the southwestern Blue Ridge. Geol Soc Am Abstr Programs 33(2):A-6

Hatcher RD Jr (1989) Tectonic synthesis of the US Appalachians. In: Hatcher RD Jr, Thomas WA, Viele GW (eds) The geology of North America: the Appalachian-Ouachita orogen in the United States. Geol Soc Am F-2:511-535

Hatcher RD Jr (1998) Structure of the Appalachian Inner Piedmont. Geol Soc Am Abstr Programs 30(4):17

Hearn PP, Sutter JF, Belkin HE (1987) Evidence for Late Paleozoic brine migration in Cambrian carbonate rocks of the central and southern Appalachians: implications for Mississippi Valley-type sulfide mineralization. Geochim Cosmochim Acta 51:13231334

Kohn MJ (2001) Timing of arc accretion in the southern Appalachians: perspectives from the Laurentian margin. Geol Soc Am Abstr Programs 33(6):A262

Leach DL, Bradley W, Lewchuk MT, Symons DTA, de Marsily G, Brannon J (2001) Mississippi Valley-type lead-zinc deposits through geologic time: implications from recent age-dating research. Miner Deposita 36:711-740

Mirante DC (2001) Monazite ages from the southern Appalachian Inner Piedmont - the Athens gneiss. Geol Soc Am Abstr Programs 33(2):A-3

Moecher DP, Miller CF (2000) Precise age for peak granulite facies metamorphism and melting in the eastern Blue Ridge from SHRIMP U-Pb analysis of zircon. Geol Soc Am Abstr Programs 32(2):A-63

Nakai S, Halliday AN, Kesler SE, Jones HD (1990) Rb-Sr dating of sphalerites from Tennessee and the genesis of Mississippi Valley-type ore deposits. Nature 346:354-357
Nakai S, Halliday AN, Kesler SE, Jones HD, Kyle JR, Lane TE (1993) $\mathrm{Rb}-\mathrm{Sr}$ dating of sphalerites from Mississippi Valley-type (MVT) ore deposits. Geochim Cosmochim Acta 57:417-427

Quinn MJ, Wright JE (1993) Extension of middle Proterozoic (Grenville) basement into the eastern Blue Ridge of southwestern North Carolina: results from $\mathrm{U} / \mathrm{Pb}$ geochronology. Geol Soc Am Abstr Programs 25(6):483-484

Ravenhurst CE, Willett SD, Donelick RA, Beaumont C (1994) Apatite fission trace thermochronometry from central Alberta: implications for the thermal history of the western Canadian sedimentary basin. J Geophys Res 99:20023-20041

Roberts MP, Finger F (1997) Do U-Pb zircon ages from granulites reflect peak metamorphic conditions? Geology 25:319-322

Rubatto D, Williams IS, Buick IS (2001) Zircon and monazite response to prograde metamorphism in the Reynolds Range, central Australia. Contrib Mineral Petrol 140:458-468

Schaltegger U, Fanning CM, Gunther D, Maurin JC, Schulmann K, Gebauer D (1999) Growth, annealing and recrystallization of zircon and preservation of monazite in highgrade metamorphism: conventional and in-situ $\mathrm{U}-\mathrm{Pb}$ isotope cathodoluminescence and microchemical evidence. Contrib Mineral Petrol 134:186-201

Symons DTA, Stratakos R (2000) Paleomagnetic dating of dolomitization and Mississippi Valley-type zinc mineralization in the Mascot-Jefferson City district of eastern Tennessee. J Geochem Explor 69-70:373-375

Symons DTA, Pan H, Sangster DF, Jowett EC (1993) Paleomagnetism of the Pine Point $\mathrm{Zn}-\mathrm{Pb}$ deposits. Can J Earth $\mathrm{Sci}$ 30:1028-1036

Symons DTA, MacDonald M, Lewchuk MR, Sangster DF (1996) Late Cretaceous age for the Monarch-Kicking Horse Mississippi Valley-type deposit in the southern Rocky Mountains of Canada from paleomagnetism. EOS 77:160

Unrug R, Ausich WI, Bednarczyk J, Cuffey RJ, Mamet BL, Palmes SL, Unrug S (2000) Paleozoic age of the Walden Creek Group, Ocoee Supergroup, in the western Blue Ridge, Southern Appalachians: implications for evolution of the Appalachian margin of Laurentia. Geol Soc Am Bull 112:982-996 